\title{
Multiple centroid method to evaluate the adaptability of alfalfa genotypes
}

\author{
Moysés Nascimento ${ }^{* 1}$, Adésio Ferreira ${ }^{2}$, Ana Carolina Campana Nascimento ${ }^{3}$, Fabyano Fonseca e Silva ${ }^{4}$, \\ Reinaldo de Paula Ferreira ${ }^{5}$, Cosme Damião Cruz ${ }^{6}$ \\ http://dx.doi.org/10.1590/0034-737X201562010004
}

\begin{abstract}
This study aimed to evaluate the efficiency of multiple centroids to study the adaptability of alfalfa genotypes (Medicago sativa L.). In this method, the genotypes are compared with ideotypes defined by the bissegmented regression model, according to the researcher's interest. Thus, genotype classification is carried out as determined by the objective of the researcher and the proposed recommendation strategy. Despite the great potential of the method, it needs to be evaluated under the biological context (with real data). In this context, we used data on the evaluation of dry matter production of 92 alfalfa cultivars, with 20 cuttings, from an experiment in randomized blocks with two repetitions carried out from November 2004 to June 2006. The multiple centroid method proved efficient for classifying alfalfa genotypes. Moreover, it showed no unambiguous indications and provided that ideotypes were defined according to the researcher's interest, facilitating data interpretation.
\end{abstract}

Key words: principal components, genotype $\mathrm{x}$ environment interaction, Medicago sativa $\mathrm{L}$.

\section{RESUMO}

\section{Metodologia dos centroides múltiplos para avaliação da adaptabilidade em genótipos de alfafa}

Este trabalho teve como objetivo avaliar a eficiência do método dos centroides múltiplos em um estudo de adaptabilidade de genótipos de alfafa (Medicago sativa L.). Neste método os genótipos são comparados a ideótipos definidos de acordo com o interesse do pesquisador por meio do modelo de regressão bissegmentada. Desta forma a classificação dos genótipos é realizada conforme objetivo do pesquisador e a estratégia de recomendação desejada. Apesar do grande potencial do método há a necessidade que o mesmo seja avaliado sob o aspecto biológico (com dados reais). Assim, diante deste contexto foram utilizados dados provenientes de um experimento em blocos casualizados com 2 repetições, que constituiu-se da avaliação da produção de

matéria seca de 92 cultivares de alfafa em 20 cortes, realizados no período de novembro de 2004 a junho de 2006. A metodologia dos Centroides Múltiplos mostrou-se eficiente na classificação de genótipos de alfafa. Além de não apresentar duplicidade de indicações e proporcionar que ideótipos fossem definidos de acordo com o interesse do pesquisador facilitando a interpretação dos dados.

Palavras-chave: componentes principais, interação genótipos x ambientes, Medicago sativa L.

\footnotetext{
Submitted on 3/05/2012 and approved on 11/19/2014

${ }^{1}$ Universidade Federal de Viçosa, Departamento de Estatística, Viçosa, Minas Gerais, Brasil. moysesnascim@ufv.br

${ }^{2}$ Universidade Federal do Espírito Santo, Centro de Ciências Agrárias, Alegre, Espírito Santo, Brasil. adesioferreira@gmail.com

${ }^{3}$ Universidade Federal de Viçosa, Departamento de Estatística, Viçosa, Minas Gerais, Brasil. ana.campana @ufv.br

${ }^{4}$ Universidade Federal de Viçosa, Departamento de Estatística, Viçosa, Minas Gerais, Brasil. fabyano.fonseca@ufv.br

5 Embrapa Pecuária Sudeste, São Carlos, São Paulo, Brasil. reinaldo@cppse.embrapa.br

${ }^{6}$ Universidade Federal de Viçosa, Departamento de Biologia Geral, Viçosa, Minas Gerais, Brasil. cdcruz @ufv.br

*Corresponding author: moysesnascim@ufv.br
} 


\section{INTRODUCTION}

In the presence of genotype by environment interaction, it is necessary to obtain detailed information on the performance of each cultivar across environmental variations (Cruz et al., 2004). Thus, the adaptability and stability analyses become extremely important and necessary in order to identify and recommend superior genotypes for different environments.

A number of methods of adaptability and stability analyses are described in the literature, including the Eberhart \& Russell (1966) and the Bayesian method proposed by Nascimento et al. (2011) that use the simple regression analysis as statistical principle. Nonparametric methods, such as those developed by Lin \& Binns (1988), Nascimento et al. (2010), centroid (Rocha et $a l ., 2005)$ and its subsequent developments the multiple centroid (Nascimento et al., 2009a) and the extended centroid (Nascimento et al., 2009b) are also reported.

Adaptability and stability analyses have been used to identify genotypes of interest in various crops. Lédo et al. (2005) conducted studies to select alfalfa genotypes with improved adaptability and stability for dry matter production. Mohebodini et al. (2006) used several methods to study in detail the genotype $\mathrm{x}$ environment interaction of 11 lentil genotypes (Lens culinaris M.). Pelúzio et al. (2008) evaluated the performance, adaptability and stability of soybean genotypes in four sowing dates, in the municipality of Gurupi, Tocantins. Mahammed \& Amri (2008) compared and evaluated the results of 20 parametric and non-parametric methods for selection of Triticum durum genotypes. In addition to these, Barreto et al. (2011) estimated the adaptability and stability of sweet potato genotypes in three environments in the South Central region of the State of Tocantins.

Among the cited methodologies, the multiple centroid method stands out in the literature as having a great potential for genotype recommendation, since the choice of the ideotypes (ideal references) is defined according to the researcher's interest using the bissegmented regression model. The method provides the researcher with a greater flexibility and genotype classification is carried out as determined by the objective of the researcher and the proposed recommendation strategy. However, despite the great potential of the method, it has not been used on actual data, hence the need to evaluate its applicability in the biological context (with real data).

Thus, this study aimed to evaluate the efficiency of the multiple centroid method in an adaptability study using real data from alfalfa genotypes (Medicago sativa L.).

\section{MATERIALAND METHODS}

The multiple centroid method requires that the environments are classified into favorable and unfavorable using the environmental index proposed by Finlay \& Wilkinson (1963):

$\mathrm{I}_{\mathrm{j}}=\frac{1}{\mathrm{~g}} \sum_{\mathrm{i}} \mathrm{Y}_{\mathrm{ij}}-\frac{1}{\mathrm{ag}} \mathrm{Y}_{.}$

where: $\mathrm{Y}_{\mathrm{ij}}$ is the average of the genotype $i$ in the environment $\mathrm{j}$; $\mathrm{Y}$.. is the total number of observations; a is the number of environments; and $g$ is the number of genotypes.

After the classification of the environments, the ideal hypothetical cultivar (ideotype), or reference, is defined by the bissegmented regression model with the following parameters: mean $\beta_{0 \mathrm{i}}$ and the linear response to unfavorable environments $\beta_{1 \mathrm{i}}$ and favorable environments $\left(\beta_{1 \mathrm{i}}+\beta_{2 \mathrm{i}}\right)$ (Cruz et al., 1989).

Using the model $\mathrm{Y}_{\mathrm{ij}}=\beta_{0 \mathrm{i}}+\beta_{1 \mathrm{i}} \mathrm{I}_{\mathrm{j}}+\beta_{2 \mathrm{i}} \mathrm{T}\left(\mathrm{I}_{\mathrm{j}}\right)$,

where: $\mathrm{Y}_{\mathrm{ij}}$ is the ideal response of the hypothetical genotype in the environment $\mathrm{j} ; \beta_{0 \mathrm{i}}$ is the value provided so that the ideal response is maximum in all sites; $\mathrm{I}_{\mathrm{j}}$ is the environment coded index; $\mathrm{T}\left(\mathrm{I}_{\mathrm{j}}\right)=0$ if $\mathrm{I}_{\mathrm{j}}<0$; and $T\left(I_{j}\right)=I_{j}-\bar{I}_{+}$if $I_{j}>0$, with the mean of the positive indices.

After establishing the centroids based on the researcher's interest, the principal component analysis is applied to obtain scores for plotting the graphs. Genotypes are classified by their position on the graphs in relation to the centroids and the Cartesian distances between points (genotypes) and each of the centroids defined by the researcher. As in the centroid method and its subsequent developments, a measure of spatial probability is calculated, which is defined as the inverse of the distance between a treatment and the ideotype defined by the researcher:

$P_{d(i, k)}=\frac{\left(\frac{1}{d_{i k}}\right)}{\sum_{i} \frac{1}{d_{i k}}}$,

where: $\mathrm{P}_{\mathrm{d}(\mathrm{i}, \mathrm{k})}$ is the probability of showing a pattern of stability similar to the $k$ th centroid; and $\mathrm{d}_{\mathrm{ik}}$ is the distance from the $i$ th genotype to $k$ th centroid.

Dry matter production data used in this study were obtained from an alfalfa evaluation experiment carried out by Southeast-Embrapa Livestock Research Center to develop alfalfa genotypes adapted to the different 
Brazilian ecosystems. The experiment evaluated the dry matter production of 92 alfalfa genotypes in 20 cuttings in a randomized block design with two replications. The cuttings were considered to be representative of different environmental conditions because they were performed at different times during the period from November 2004 to June 2006.

The ideotypes for the method were defined according to Pereira \& Ferreira (2008), considering that when the interest is the genetic improvement, one selects alfalfa genotypes in which a good performance for dry matter production is coupled with a high response to environment improvement and highly predictable behavior. Thus, using the bissegmented regression model, the following references of interest were created: ideotype I - mean higher than the overall mean of the assessed alfalfa genotypes and with general adaptability as $\left(\beta_{01}>X_{G} ; \beta_{1 \mathrm{i}}=1\right)$; ideotype II - mean higher than the overall mean and responsive to environmental changes $\left(\beta_{0}>\bar{X}_{\mathrm{G}} ; \beta_{1 \mathrm{i}}+\beta_{2 \mathrm{i}}=1,5\right)$; and for discard: ideotype III general adaptability with mean lower than the general mean $\left(\beta_{0 \mathrm{i}}<\overline{\mathrm{X}}_{\mathrm{G}} ; \beta_{\mathrm{li}}=1\right)$, mathematically:

I. $\quad \mathrm{Y}_{\mathrm{ij}}=\left(>\overline{\mathrm{X}}_{\mathrm{G}}\right)+\mathrm{I}_{\mathrm{j}}$;

II. $\quad \mathrm{Y}_{\mathrm{ij}}=\left(>\overline{\mathrm{X}}_{\mathrm{G}}\right)+0.5 \mathrm{I}_{\mathrm{j}}+1 \mathrm{~T}\left(\mathrm{I}_{\mathrm{j}}\right)$;

III. $\quad Y_{\mathrm{ij}}=\left(<\bar{X}_{\mathrm{G}}\right)+\mathrm{I}_{\mathrm{j}}$.

The results obtained from the multiple centroid method were also compared with the non-parametric methodology by Lin \& Binns (1988).

The statistical analyses were carried out using the GENES software (Cruz, 2006) available at http:// www.ufv.br/dbg/genes/gdown.htm.

\section{RESULTS AND DISCUSSION}

There was significant difference among dry matter production means of the alfalfa cultivars and significant cultivar $(\mathrm{Cv}) \mathrm{x}$ cutting $(\mathrm{Ct})$ interaction, at 5 and $1 \%$ probability levels, respectively (Table 1 ). The significance of the cultivar $\mathrm{x}$ cutting interaction shows that the cultivars had different performances in the various environmental conditions. Therefore, this interaction was studied in more detail using the analyses of adaptability and stability.

The ideotypes based on the work of Pereira \& Ferreira (2008) and defined by the bissegmented regression model were characterized as follows:

I $\quad \mathrm{Y}_{\mathrm{ij}}=1.250+1 \mathrm{I}_{\mathrm{j}}$;

II $\quad \mathrm{Y}_{\mathrm{ij}}=1.300+1 \mathrm{Ij}+0,5 \mathrm{I}$;

III $\quad \mathrm{Y}_{\mathrm{ij}}=1.100+1 \mathrm{I}_{\mathrm{j}}$.
Ideotype I is a genotype with general adaptability with mean higher than the overall mean, which is of interest for breeding programs with a wide range of environments. Ideotype II is responsive to environment improvement and of great interest for alfalfa breeding (Pereira \& Ferreira, 2008). Ideotype III has lower mean than the overall mean and can be discarded.

In the Principal Components Analysis, the cumulative percentage of variance in the first three components explained $75.44 \%$ of the variability in the data (Table 2), which, according to Johnson \& Wichern (1992) and Melém Júnio. et al. (2008), is sufficient to a satisfactory interpretation of the results.

The genotypes were classified according to the multiple centroid method (Table 3). Of the 92 alfalfa

Table 1. Summary of the analysis of variance for the trait dry matter production of 92 alfalfa cultivars in 20 environments (cuttigs), in the municipality of São Carlos / SP, from November 2004 to June 2006

\begin{tabular}{lrc}
\hline Sources of variation & \multicolumn{1}{c}{ DF } & Mean Squares \\
\hline Blocks & 1 & 2002415.43 \\
Cultivar (Cv) & 91 & $1384475.75^{*}$ \\
Error a & 91 & 574269.72 \\
Cutting $(\mathrm{Ct})$ & 19 & $62331022.56^{*}$ \\
Error b & 19 & 946917.67 \\
Interaction $(\mathrm{Cv}$ x Ct) & 1729 & $60682.46^{* *}$ \\
Error c & 1729 & 55851.26 \\
Mean & 1176.80 & \\
\hline
\end{tabular}

NS non-significant; $*$ and $* *$ - significant at 5 and $1 \%$ probability levels, respectively, by the $\mathrm{F}$ test

Table 2. Variance estimates (eigenvalues) of principal components and cumulative percent of variance explained by the components

\begin{tabular}{rcc}
\hline Root & Root $(\boldsymbol{\%})$ & \% Accumulated \\
\hline 12.210 & 61.050 & 61.050 \\
1.596 & 7.980 & 69.030 \\
1.282 & 6.412 & 75.443 \\
0.811 & 4.057 & 79.500 \\
0.699 & 3.494 & 82.994 \\
0.539 & 2.696 & 85.690 \\
0.459 & 2.294 & 87.985 \\
0.401 & 2.004 & 89.989 \\
0.360 & 1.801 & 91.790 \\
0.320 & 1.599 & 93.389 \\
0.234 & 1.170 & 94.560 \\
0.210 & 1.052 & 95.612 \\
0.176 & 0.879 & 96.491 \\
0.156 & 0.781 & 97.271 \\
0.143 & 0.717 & 97.989 \\
0.124 & 0.621 & 98.610 \\
0.085 & 0.425 & 99.036 \\
0.074 & 0.369 & 99.404 \\
0.065 & 0.326 & 99.731 \\
0.054 & 0.269 & 100.000 \\
\hline
\end{tabular}


Table 3. Classification and probability associated with the genotypes in each of the three groups characterized by the ideotypes defined by Multiple Centroid Method (MCM) and estimates of stability and adaptability by the Lin \& Binns (1988) method for the trait dry matter production

\begin{tabular}{|c|c|c|c|c|c|c|c|c|c|}
\hline \multirow[t]{2}{*}{ Genotype } & \multirow[b]{2}{*}{ Mean } & \multicolumn{2}{|c|}{ MCM } & \multicolumn{6}{|c|}{ Lin \& Binns (1988) } \\
\hline & & Clas. & Prob. & Clas. & $\mathbf{P}_{i}$ & Clas. & $P_{i}$ fav. & Clas. & $P_{i}$ unfav. \\
\hline Winter & 1002.851 & III & 0.499 & 45 & 235472.34 & 41 & 37180.94 & 45 & 223575.45 \\
\hline SPS 6550 & 1133.702 & III & 0.473 & 41 & 262956.04 & 37 & 60064.99 & 66 & 415696.31 \\
\hline Primavera & 1052.277 & III & 0.439 & 17 & 292152.13 & 17 & 78710.83 & 41 & 447681.11 \\
\hline LE N 1 & 1184.557 & I & 0.464 & 32 & 306196.73 & 32 & 84947.67 & 17 & 466785.92 \\
\hline Trindade 87 & 1467.199 & I & 0.383 & 63 & 329223.96 & 63 & 95972.39 & 32 & 487218.69 \\
\hline LE N 2 & 1352.261 & I & 0.442 & 5 & 337543.51 & 76 & 104554.55 & 18 & 503535.04 \\
\hline LE Semit 711 & 1140.254 & III & 0.419 & 33 & 339018.09 & 33 & 107414.39 & 9 & 510865.03 \\
\hline Topper & 1144.191 & III & 0.394 & 66 & 340669.40 & 38 & 111939.38 & 63 & 520066.15 \\
\hline LE N 3 & 1394.53 & I & 0.364 & 76 & 350884.22 & 5 & 112580.47 & 5 & 521604.17 \\
\hline Sequel HR & 1306.674 & I & 0.486 & 31 & 356239.01 & 10 & 126967.34 & 33 & 528512.02 \\
\hline LE N 4 & 1382.655 & I & 0.376 & 9 & 357513.50 & 36 & 129803.04 & 31 & 541067.87 \\
\hline Victoria INTA & 1213.572 & I & 0.471 & 18 & 358002.24 & 65 & 129983.92 & 76 & 552426.67 \\
\hline Monarca INTA & 1189.032 & I & 0.489 & 38 & 359788.25 & 31 & 130337.06 & 38 & 562573.68 \\
\hline Bárbara INTA & 1315.94 & I & 0.425 & 37 & 369277.02 & 11 & 133563.51 & 11 & 577633.17 \\
\hline Primavera 1 & 1196.396 & I & 0.442 & 11 & 377801.82 & 6 & 135995.01 & 6 & 580475.23 \\
\hline Aca 900 & 1273.347 & I & 0.456 & 6 & 380459.13 & 43 & 138401.46 & 36 & 590067.59 \\
\hline 5939 & 1574.601 & II & 0.393 & 36 & 382948.54 & 30 & 145691.65 & 61 & 590308.28 \\
\hline WL 612 & 1399.081 & I & 0.383 & 59 & 395931.76 & 59 & 155565.54 & 59 & 592595.03 \\
\hline Medina & 1251.655 & I & 0.425 & 65 & 398478.66 & 58 & 160601.77 & 14 & 593962.81 \\
\hline N910 & 1183.788 & I & 0.411 & 61 & 399834.18 & 61 & 167032.49 & 78 & 598936.43 \\
\hline Coronado & 793.913 & III & 0.43 & 14 & 414808.50 & 9 & 170083.85 & 19 & 601920.19 \\
\hline Eterna & 835.141 & III & 0.445 & 10 & 425684.84 & 75 & 174267.94 & 16 & 610069.93 \\
\hline DK 193 & 915.606 & III & 0.429 & 43 & 426010.42 & 40 & 176812.57 & 65 & 618156.18 \\
\hline Candombe & 651.019 & III & 0.397 & 78 & 431208.54 & 77 & 178856.38 & 60 & 618907.58 \\
\hline WL 414 & 830.552 & III & 0.43 & 58 & 434807.11 & 34 & 179851.14 & 37 & 622268.69 \\
\hline Crioula & 1033.33 & III & 0.53 & 60 & 437716.42 & 18 & 180128.82 & 49 & 625826.26 \\
\hline LE Semit 7111 & 991.079 & III & 0.492 & 16 & 437758.62 & 42 & 186655.01 & 29 & 629687.61 \\
\hline DK 181 & 1053.433 & III & 0.501 & 34 & 437994.65 & 83 & 188201.72 & 52 & 633972.21 \\
\hline 5929 & 1264.671 & I & 0.484 & 80 & 439337.39 & 35 & 189398.13 & 80 & 642935.34 \\
\hline Activa & 1257.95 & I & 0.405 & 77 & 439439.26 & 80 & 190495.44 & 39 & 642976.43 \\
\hline Sequel 2 & 1411.095 & I & 0.388 & 35 & 443438.82 & 14 & 195842.11 & 34 & 649202.98 \\
\hline Califónia 60 & 1525.046 & II & 0.366 & 39 & 443590.45 & 39 & 199896.47 & 35 & 651290.30 \\
\hline Cuf 101 & 1437.202 & I & 0.394 & 75 & 444914.75 & 57 & 200187.51 & 77 & 652643.42 \\
\hline 58 N 58 & 1263.816 & I & 0.485 & 19 & 444991.67 & 64 & 202143.70 & 58 & 659156.93 \\
\hline Diamind & 1277.022 & I & 0.445 & 52 & 446558.49 & 13 & 210902.64 & 43 & 661326.84 \\
\hline Aurora & 1336.743 & I & 0.413 & 29 & 448317.80 & 4 & 211621.99 & 12 & 662027.33 \\
\hline Sundor & 1428.926 & I & 0.392 & 49 & 449907.69 & 55 & 216249.71 & 75 & 666353.04 \\
\hline Springfield & 1383.944 & I & 0.419 & 30 & 464164.23 & 60 & 216260.57 & 10 & 670090.07 \\
\hline Sutter & 1211.478 & I & 0.462 & 12 & 477254.08 & 52 & 217497.27 & 79 & 672229.49 \\
\hline Hunterfield & 1189.427 & I & 0.424 & 62 & 479016.65 & 7 & 222260.92 & 62 & 672375.93 \\
\hline P 105 & 1622.763 & II & 0.362 & 79 & 481318.79 & 44 & 222944.05 & 50 & 682165.17 \\
\hline Prointa Patricia & 1184.066 & I & 0.449 & 50 & 482536.00 & 78 & 226207.79 & 20 & 687557.17 \\
\hline Flórida 77 & 1288.054 & I & 0.452 & 15 & 491489.51 & 29 & 226643.59 & 8 & 690074.52 \\
\hline Siriver 2 & 1185.93 & I & 0.503 & 42 & 491885.34 & 16 & 227155.91 & 15 & 705311.63 \\
\hline WL 516 & 1334.343 & II & 0.338 & 40 & 492310.72 & 15 & 230151.35 & 74 & 717152.06 \\
\hline Tahoe & 1041.086 & III & 0.513 & 44 & 498105.18 & 86 & 230334.96 & 81 & 719196.74 \\
\hline Esmeralda & 1081.97 & III & 0.516 & 83 & 502460.53 & 82 & 231524.21 & 71 & 720367.64 \\
\hline DK 167 & 1122.714 & III & 0.475 & 4 & 503848.43 & 49 & 234896.10 & 44 & 723237.02 \\
\hline DK 177 & 1274.64 & I & 0.437 & 20 & 505046.01 & 50 & 238544.80 & 30 & 724732.69 \\
\hline 5683 & 1205.993 & I & 0.486 & 13 & 508807.97 & 62 & 242688.65 & 56 & 725279.11 \\
\hline WL 4141 & 1010.343 & III & 0.501 & 82 & 513204.27 & 79 & 247983.49 & 90 & 727153.04 \\
\hline
\end{tabular}


Continuação...

\begin{tabular}{|c|c|c|c|c|c|c|c|c|c|}
\hline \multirow[t]{2}{*}{ Genotype } & \multirow[b]{2}{*}{ Mean } & \multicolumn{2}{|c|}{ MCM } & \multicolumn{6}{|c|}{ Lin \& Binns (1988) } \\
\hline & & Clas. & Prob. & Clas. & $\mathbf{P}_{i}$ & Clas. & $P_{i}$ fav. & Clas. & $P_{i}$ unfav. \\
\hline Express & 1267.468 & I & 0.459 & 57 & 515157.44 & 66 & 248969.83 & 42 & 741619.25 \\
\hline F 708 & 1108.731 & III & 0.505 & 56 & 519602.71 & 45 & 250012.98 & 54 & 741980.19 \\
\hline Perla INTA & 1129.403 & III & 0.495 & 90 & 520874.07 & 48 & 250084.75 & 4 & 742942.78 \\
\hline Prointa Lujan & 1088.188 & III & 0.456 & 81 & 531261.57 & 12 & 251420.10 & 82 & 743669.78 \\
\hline DK 166 & 1150.3 & I & 0.413 & 54 & 535170.87 & 19 & 253190.14 & 40 & 750445.57 \\
\hline Platino & 1179.549 & I & 0.44 & 2 & 547132.91 & 2 & 263962.50 & 13 & 752548.70 \\
\hline Maxidor & 1274.525 & I & 0.475 & 71 & 549586.81 & 56 & 268220.46 & 87 & 752835.68 \\
\hline Amerigraze701 & 1355.009 & I & 0.424 & 86 & 554039.38 & 90 & 268755.32 & 88 & 757295.23 \\
\hline 13 R Supreme & 1270.49 & I & 0.486 & 8 & 554619.87 & 46 & 272116.87 & 83 & 759581.37 \\
\hline Pecos & 1322.879 & I & 0.463 & 53 & 560568.51 & 53 & 274909.98 & 57 & 772860.10 \\
\hline Califórnia 50 & 1211.353 & I & 0.48 & 48 & 566289.10 & 20 & 281976.82 & 84 & 777777.82 \\
\hline Maricopa & 1459.601 & I & 0.375 & 64 & 571848.02 & 54 & 282403.92 & 2 & 778817.79 \\
\hline Kern & 1120.366 & III & 0.416 & 7 & 581177.86 & 28 & 295297.47 & 73 & 783982.29 \\
\hline Costera INTA & 1357.178 & I & 0.422 & 84 & 582795.17 & 81 & 301563.02 & 3 & 791458.63 \\
\hline F 686 & 1271.352 & I & 0.395 & 55 & 584800.90 & 1 & 307733.23 & 53 & 794289.13 \\
\hline Monarca & 1034.199 & III & 0.535 & 74 & 587982.62 & 47 & 319583.61 & 67 & 811667.00 \\
\hline Patrícia & 971.805 & III & 0.486 & 47 & 598152.14 & 26 & 328898.10 & 86 & 818888.46 \\
\hline Tango & 804.511 & III & 0.439 & 88 & 601359.98 & 51 & 333057.38 & 48 & 825001.75 \\
\hline Bárbara & 872.003 & III & 0.437 & 73 & 605967.74 & 71 & 340854.69 & 47 & 826071.85 \\
\hline Rio Grande & 1116.735 & III & 0.439 & 67 & 607833.35 & 84 & 344483.05 & 27 & 848775.18 \\
\hline Key II & 904.77 & III & 0.436 & 28 & 611185.60 & 67 & 358703.35 & 89 & 854982.88 \\
\hline Gala & 1041.232 & III & 0.519 & 46 & 621245.02 & 68 & 378522.17 & 85 & 867773.36 \\
\hline Lujan & 1131.267 & III & 0.389 & 26 & 627654.51 & 73 & 388394.41 & 28 & 869639.53 \\
\hline Perla & 1252.125 & I & 0.482 & 51 & 635286.40 & 8 & 389064.19 & 26 & 872091.56 \\
\hline $5683 \mathrm{~L}$ & 1404.397 & I & 0.397 & 87 & 636339.60 & 72 & 405143.81 & 64 & 874333.38 \\
\hline Victoria & 1283.158 & I & 0.436 & 3 & 636876.92 & 88 & 410772.45 & 7 & 874837.17 \\
\hline DK 194 & 1300.291 & I & 0.426 & 1 & 657604.37 & 74 & 430108.85 & 51 & 882564.69 \\
\hline WL 442 & 1194.413 & I & 0.49 & 27 & 669589.00 & 3 & 447943.73 & 55 & 886342.78 \\
\hline P 30 & 1259.664 & I & 0.501 & 85 & 681077.22 & 91 & 447965.36 & 46 & 906895.33 \\
\hline P 5715 & 1141.713 & III & 0.447 & 68 & 686745.10 & 27 & 450583.67 & 91 & 915265.24 \\
\hline Alfa 200 & 1165.585 & I & 0.465 & 91 & 704980.30 & 85 & 452893.05 & 68 & 938927.49 \\
\hline Aca 901 & 1200.671 & I & 0.417 & 89 & 715246.96 & 87 & 493955.50 & 1 & 943862.57 \\
\hline Gapp 969 & 1093.061 & III & 0.512 & 72 & 761389.50 & 23 & 529952.30 & 25 & 957100.39 \\
\hline Rocio & 974.527 & III & 0.485 & 23 & 776073.87 & 89 & 544458.62 & 70 & 970024.80 \\
\hline GT 13 R Plus & 1143.141 & III & 0.433 & 70 & 792140.75 & 22 & 566244.10 & 23 & 977446.06 \\
\hline WL 525 & 1013.744 & III & 0.468 & 25 & 818314.66 & 70 & 574726.91 & 21 & 1028229.01 \\
\hline Sequel & 1056.443 & III & 0.491 & 22 & 823283.57 & 92 & 619670.22 & 22 & 1033588.58 \\
\hline DK 187 R & 934.305 & III & 0.426 & 69 & 857406.25 & 69 & 630696.17 & 69 & 1042896.33 \\
\hline Pinto & 1148.741 & III & 0.427 & 21 & 868788.76 & 25 & 648687.66 & 72 & 1052863.23 \\
\hline Bacana & 939.335 & III & 0.481 & 92 & 969241.67 & 21 & 673917.34 & 24 & 1109434.51 \\
\hline Siriver & 718.896 & III & 0.418 & 24 & 1059743.34 & 24 & 999009.68 & 92 & 1255254.68 \\
\hline
\end{tabular}

genotypes, 49 were classified as having high general adaptability with means higher than the overall mean of the experiment (ideotype I), four were classified as specific for favorable environments (ideotype II) and 39 as having general adaptability with means lower than the overall mean (ideotype III) (Table 3).

Among the 49 genotypes classified as ideotype I, ten showed greater probabilities, including Siriver 2 (0.503); P 30 (0.501); WL 442 (0.490); Monarca INTA (0.489); 5683 (0.486); Sequel HR (0.486); 13 R Supreme
(0.486); 58 N 58 (0.485); 5929 (0.484); and Perla (0.485). These genotypes can be recommended to sites with large environmental variability. The genotypes classified as ideotype II of great interest for alfalfa breeding programs were: 5939 (0.393); Califonia 60 (0.366); P 105 (0.362); and WL 516 (0.338).

Among the 39 genotypes classified as ideotype III, which can be discarded, the ten with the largest probabilities were: Monarca (0.535); Crioula (0.530); Gala (0.520); Esmeralda (0.516); Tahoe (0.513); Gapp 
969 (0.512); F 708 (0.505); DK 181 (0.501); WL 4141 (0.501); and Winter (0.501).

The first three principal components scatterplot of the 92 genotypes in twenty environments (cuttings) showed a mass of genotypes around the ideotypes I and III, which confirms the results presented (Figure 1).

The genotypes were also analyzed by the method of Lin \& Binns (1988) (Table 3). The results showed that the first five genotypes classified as of general adaptability were: WL 516; P 105; 5939; California 60; and Maricopa. The first five genotypes classified as adaptable to favorable environment were: P 107; Sundor. 5 939; California 60; and Maricopa. The genotypes WL 516, F 686, P 105, 5939 and Maricopa were the first five classified as adaptable to unfavorable environments.

The four genotypes classified as adaptable to favorable environments by the multiple centroid method were also classified as of general adaptability by the method of Lin \& Binns (1988). Besides, of these four genotypes, two, 5939 and California 60, were also classified as of specific adaptability to favorable environments. Among those that can be discarded, which were classified as ideotype III by the multiple centroids and of specific adaptability to unfavorable environments by Lin \& Binns (1988), none showed equivalent classification.

The results of this study corroborate the work of Nascimento et al. (2009a) and demonstrate the ease of analysis and interpretation of adaptability by the multiple centroid method compared to the method of Lin \& Binns (1988). This easiness is due to the non-occurrence of possible ambiguous indications in the multiple centroid method, as it happens in the Lin \& Binns (1988) method, as well as the direct comparison with the ideotype of interest.

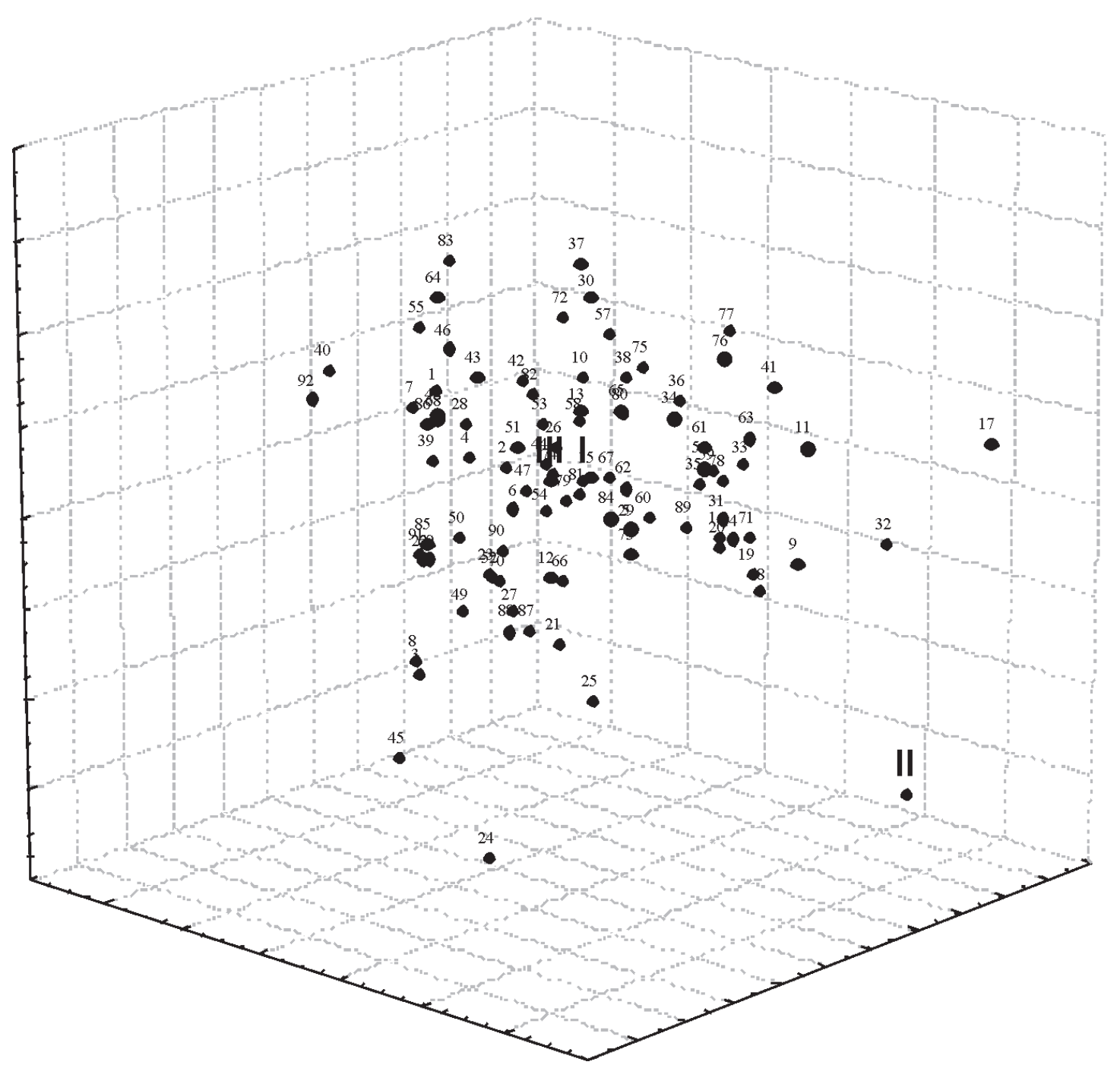

Figure 1. Scatterplot of the first three principal components of 92 genotypes for the response of dry matter production to twenty environments (cuttings). The three points numbered with Roman numerals represent the centroids. 


\section{CONCLUSIONS}

The multiple centroid method was efficient to classify alfalfa genotypes without showing ambiguous information as it occurs with the Lin \& Binns (1988) method. Furthermore, the definition of ideotypes according to the researcher's interest facilitated data interpretation.

\section{REFERENCES}

Barreto HG, Santos LB dos, Oliveira GÍS de, Santos GR do, Fidelis RRF, Silveira MA da \& Nascimento IR do (2011) Estabilidade e adaptabilidade da produtividade e da reação a insetos de solo em genótipos experimentais e comerciais de batata-doce. Bioscience Journal, 27:739-747

Cruz CD (2006) Programa Genes - Biometria. $1^{\mathrm{a}}$ ed. Viçosa, Editora UFV $382 \mathrm{p}$.

Cruz CD, Torres RA \& Vencovsky R (1989) An alternative approach to the stability analysis proposed by Silva and Barreto. Revista Brasileira de Genética, 12:567-80.

Cruz CD, Regazzi AJ \& Carneiro PC (2004) Modelos biométricos aplicados ao melhoramento genético. $3^{\mathrm{a}}$ ed. Viçosa, Editora UFV. 480p.

Eberhart SA \& Russell WA (1966) Stability parameters for comparing varieties. Crop Science, 6:36-40.

Finlay KW \& Wilkinson GN (1963) The analysis of adaptation in a plant-breeding programme. Australian Journal of Agricultural Research,14:742-754.

Johnson RA \& Wichern DW (1999) Applied multivariate statistical analysis. $4^{\mathrm{a}}$ ed. New Jersey, Prentice-Hall. 815p.

Lédo FJ da S, Botrel M de A, Evangelista AR, Viana MCM, Pereira AV, Souza Sobrinho F de, Oliveira JS e, Xavier DF \& Heinemann AB (2005) Adaptabilidade e estabilidade de cultivares de alfafa avaliadas em Minas Gerais. Ciência e Agrotecnologia, 29:409-414.

Lin CS \& Binns MR (1988) A superiority measure of cultivar performance for cultivar x location data. Canadian Journal of Plant Science, 68:193-198

Mahammadi R \& Amri A (2007) Comparison of parametric and nonparametric methods for selecting stable and adapted durum wheat genotypes in variable environments. Euphytica, 159:419-432.

Melém Júnior NJ, Fonseca IC de B, Brito OR, Decaëns T, Carneiro MM, Matos M de FA de, Guedes MC, Queiroz JAL de \& Barroso K de O (2008) Análise de componentes principais para avaliação de resultados analíticos da fertilidade de solos do Amapá. Semina. Ciências Agrárias, 29:499 506.

Mohebodini M, Dehghani H \& Sabaghpour SH (2006) Stability of performance in lentil (Lens culinaris Medik) genotypes in Iran. Euphytica, 149:343-352.

Nascimento M, Ferreira A, Campana ACM, Salgado CC \& Cruz CD (2009a) Multiple centroid methodology to analyze genotype adaptability. Crop Breeding and Applied Biotechnology, 9:08-16.

Nascimento M, Cruz CD, Campana ACM, Tomaz RS, Salgado CC, Ferreira $\mathrm{R}$ de $\mathrm{P}$ (2009b) Alteração no método centroide de avaliação da adaptabilidade genotípica. Pesquisa Agropecuária Brasileira, 44:263-269.

Nascimento M, Ferreira A, Ferrão RG, Campana ACM, Bhering LL, Cruz CD, Ferrão MAG \& Fonseca AFA da (2010) Adaptabilidade e estabilidade via regressão não paramétrica em genótipos de café. Pesquisa Agropecuária Brasileira, 45:45-48.

Nascimento M, Silva FF, Sáfadi T, Nascimento ACC, Ferreira RP \& Cruz CD (2011) Abordagem bayesiana para avaliação da adaptabilidade e estabilidade de genótipos de alfafa. Pesquisa agropecuária brasileira, 46:26-32.

Rev. Ceres, Viçosa, v. 62, n.1, p. 030-036, jan/fev, 2015
Pelúzio JM, Fidelis RR, Giongo P, Silva JC da, Cappelari D \& Barros HB (2008) Adaptabilidade e estabilidade de cultivares de soja em quatro épocas de semeadura no sul do Estado do Tocantins. Revista Ceres, 55:034-040.

Pereira AV \& Ferreira RP (2008) Cultivares de alfafa. In: Ferreira RP, Rassini JB, Rodrigues AA, Freitas AR, Camargo AC \& Mendonça FC (Eds.). Cultivo e utilização da alfafa nos trópicos. São Carlos, Embrapa Pecuária Sudeste. p.193-214.

Rocha RB, Abad JIM, Araujo EF \& Cruz CD (2005) Avaliação do método centroide para estudo de adaptabilidade ao ambiente de clones de Eucalyptus grandis. Ciência Florestal, 15:255-266. 